This is a pre-print version of an article published in CONSTITUTIONAL POLITICAL ECONOMY (Spinger), Gordon Tullock and the Virginia School of Law and Economics, Parisi F.; Luppi B.; Guerra A., 2017.

The final authenticated version is available online at: http://dx.doi.org/10.1007/s10602-016-9216$\underline{8}$

This version is subjected to Springer Nature terms for reuse that can be found at: https://www.springer.com/gp/open-access/authors-rights/aam-terms-v1 


\title{
Francesco Parisi ${ }^{1}$ - Barbara Luppi ${ }^{2}$ - Alice Guerra $^{3}$ \\ Gordon Tullock and the \\ Virginia School of Law and Economics
}

\author{
March 6, 2016
}

\begin{abstract}
In 1999 Gordon Tullock became Professor at the George Mason University Law School. Tullock's arrival at George Mason brought the economics department and the law school close together. The work that resulted during those years consolidated the methodological foundations for a different way of thinking about the economic analysis of law -- the "functional" approach to law and economics. The functional law and economics approach espoused by the Virginia School was not attacking any of the results of the Chicago School or the Yale School, but rather proposing a methodological shift. This paper presents some of the results developed by this school and illustrates Tullock's controversial positions on trials and on the common law system, through anecdotes, Tullock's own work and related scholarly contributions.
\end{abstract}

Gordon Tullock's intellectual legacy spans a wide range of subjects, from constitutional political economy and public choice to bureaucracy, law, and bioeconomics (Rowley, 2012). Tullock distinguished himself as an economist through his vigorous dissent from mainstream economic analysis, and simultaneously

\footnotetext{
${ }^{1}$ F. Parisi, University of Minnesota Law School and Department of Economics, University of Bologna, Italy. Email: parisi@umn.edu. An earlier version of this paper was presented by Francesco Parisi at the memorial lectures for Gordon Tullock, organized by the Public Choice Society in 2015. The anecdotes and personal memories are by Francesco Parisi.

2 B. Luppi. Department of Economics, University of Modena and Reggio Emilia, Italy. Email: barbara.luppi@unimore.it

${ }^{3}$ A. Guerra. Department of Business and Politics, Copenhagen Business School. Email: agu.dbp@cbs.dk.
} 
contributed essentially to the foundation of the functional school of law and economics.

Rather than focusing on his extensive scholarship, this article intends to provide an overview of some of Tullock's writings, as well as personal memories of the beginning of Tullock's academic career at law school. The work that resulted from those years consolidated the methodological foundations of a different way of thinking about the economic analysis of law, now called the "functional" approach to law and economics. This functional approach to law and economics, as espoused by the Virginia School, was not attacking any of the results of the Chicago School or the Yale School, but rather proposed a methodological shift. This paper presents some of the results developed by this school and illustrates Tullock's controversial positions on trials and on the common law system through anecdotes, Tullock's own work, and related scholarly contributions.

The paper is divided into three sections. In the first section, we discuss Gordon Tullock's intellectual background and his academic career through personal anecdotes of Prof. Parisi, who was his colleague at that time at George Mason University School of Law. During his tenure at the law school Tullock contributed to laying the intellectual foundations for a functional approach to law and economics. We discuss Tullock's functional approach to law and economics scholarship, also in the light of Prof. Parisi's personal experiences with Tullock. In the second section, we provide an overview of Tullock's reasoning concerning the relative merits of the common and continental law, and of fee-shifting (English versus American) rules. We also discuss some extensions to examine institutional differences of adversarial versus inquisitorial legal systems and, specifically, how 
fee-shifting rules affect the evolution of common law systems. The third section concludes with some final considerations about Gordon Tullock's legacy in law and economics.

\section{Gordon Tullock: The Law and Economics Scholar}

Gordon Tullock was a lawyer by training and an economist by nature, so it is not surprising that he contributed to legal scholarship, becoming a pioneer in law and economics. He received his JD from the University of Chicago Law School in 1947. He also joined the Foreign Service in 1947, but in the few months in between, he practiced law in downtown Chicago.

As an academic, Tullock held academic positions in political science, economics, and international studies departments, but it was not until his later years that he transitioned full time to legal academia. In the following, we provide a personal account of Gordon Tullock's years as a legal academic, followed by a discussion of his important role in setting the methodological foundations for the functional approach to law and economics.

\subsection{Gordon Tullock's Early Steps at the Law School}

Despite his educational background in law and his academic interest in law, it was not until 1999 that he joined a law faculty, at the George Mason University School of Law. $\mathrm{I}^{4}$ personally voted on Gordon Tullock's hiring when I was a professor at George Mason University School of Law. As is customary, the hiring of a full professor at George Mason requires three faculty votes: in the first round,

\footnotetext{
${ }^{4}$ The anecdotes and personal memories here are courtesy of Prof. Parisi, who was a colleague of Prof. Tullock's when he joined the Law Faculty at George Mason University.
} 
the entire faculty votes for the faculty appointment of the candidate, then the tenured faculty votes to grant tenure, and finally the full professors vote to grant full professorship to the new hire. Thus, as a newly promoted full professor, I got to vote three times on Gordon Tullock's appointment. Tullock's appointment was a no-brainer to all of us. Interestingly, however, I detected some unspoken concerns as the voting moved up the ranks. George Mason's law deans followed the practice of linking salary increases and summer research grants to a faculty member's citation count and publication record. Tullock had almost as many citations as the rest of our faculty put together, so some concern arose that Tullock could absorb the greater part of the discretionary faculty budget for himself.

Budget concerns aside, Tullock's arrival at the law school was cheered by all of us. His affiliation was at the law school and his office was in the wing of the law school next to Institute of Humane Studies and Mercatus Center - organizations with which Tullock shared great intellectual affinity. During those years, the J.M. Buchanan Center for Political Economy created a program in law and economics, which was co-directed by Charles Rowley and myself. These events were followed by the arrival of Vernon L. Smith and his experimental lab and the creation of a $\mathrm{JD} / \mathrm{PhD}$ joint degree program in law and economics. These brought the economics department and the law school closer together. Thanks to the prior pioneering efforts of Dean Henry G. Manne, George Mason was already academically known for its strong emphasis on economic analysis of law, and the arrival of Gordon Tullock and Vernon Smith brought the George Mason School of Law and Economics to the forefront of academic and scientific research.

In the years 1999 and 2000, the J.M. Buchanan Center for Political Economy organized a series of lectures that were subsequently published in a volume titled "The Origins of Law and Economics". For these lectures, all of the "founding 
fathers" of the field were invited, whether from the Yale School, the Chicago School, or other universities, and were asked to present papers on the origins and methodological foundations of law and economics.

Tullock attended all lectures and joined the speakers for the dinners that followed their presentations. I was also present at these dinners, and I had the privilege of witnessing the interactions and conversations that Tullock had with the presenters.

While Gordon Tullock's academic recognition in the public choice community was gronded on his many contributions to the field - from his rentseeking models to his co-authored Calculus of Consent - his reputation in the law and economics community was mostly tied to one specific contribution - his 1971 book The Logic of the Law. Tullock's book was novel and yet controversial or his time, and set Tullock apart - isolated, one might say - from the other early contributors to law and economics. Unlike his contemporaries who attempted to highlight the compatibility of the efficiency criterion with ethical and moral principles, Tullock ventured on a solitary mission, developing a non-ethical foundation for law. His attempt to deduce legal principles that were not based on ethics or morality, but rather deduced from a framework of Pareto optimality was met with skepticism by his contemporary fellow academics. His framework was rooted on three, fairly non-controversial assumptions: (1) equality under the law; (2) self-interest of the subjects of the law; and (3) individual choice and revealed preferences. For a quarter of a century, Tullock's framework remained unappreciated and virtually ignored by legal and economic scholars - concerned as they were about reconciling efficiency with ethics and morality, rather than highlighting the ethical and moral foundations of the efficiency criterion. 


\subsection{Tullock and the Functional Approach to Law and Economics}

When Tullock entered legal academia at George Mason School of Law, it became immediately clear that he was a scholar of a different kind. He obviously believed that law could be an important instrument to promote social welfare. But Tullock was not at ease with the "positive" economic analysis of the Chicago school, and with the idea that common law rules evolve spontaneously toward efficiency through a process of natural selection, and he was similarly skeptical of the "normative approach" of the Yale school, which in Tullock's view excessively focused on market failures and the design of laws to correct them. In 2001, Richard Posner and I described Tullock's approach as the "functional" approach, which is closely tied to the Virginia school of Public Choice theory (Posner and Parisi, 1999).

The functional approach to law and economics stands at the interface of law, economics, and public choice theory. It relates to the standard law and economics approach as constitutional and political economy relate to public choice theory. The functional law and economics approach is normative at the meta-level. In other words, while it is normative in the sense that it attempts to identify mechanisms for producing healthy and efficient laws, it is not normative at the micro "rule" level. It does not use economics to test whether any specific substantive law is efficient or not. Instead, it uses economics to test whether or not a lawmaking process is free from collective decision-making failures.

For a quarter of a century, Tullock's framework remained unappreciated and virtually ignored by legal and economic scholars - concerned as they were about reconciling efficiency with ethics and morality, rather than highlighting the ethical and moral foundations of the efficiency criterion. Tullock's methodological 
premises, as expressed in his 1971 The Logic of the Law proved particularly valuable in setting the foundations for the functional approach to law and economics. Tullock's system, built on equality, methodological individualism and revealed preference, gave renewed relevance to the Pareto efficiency criterion in law. Law and economics scholars had until that point dismissed the Pareto criterion as useless for legal policy making. How would it possible to make any legal change without negatively affecting at least somebody in society, Calabresi (1991) asked. Tullock's framework was instead entirely built on the Pareto criterion. Equal citizens, moved by self-interest, could reveal their true preferences over alternative legal rules. The pursuit of individual interests would lead to collective well-being. The only task for legal policymakers would be that of creating institutions and mechanisms of choice that would induce individuals to reveal their true preferences through choice.

The best way to describe the resulting functional approach of the Virginia school is to use a metaphor used by Robert Cooter (who became editor, with Daniel Rubinfeld, of the International Review of Law and Economics after Charles Rowley and Anthony Ogus stepped down in 1988). Cooter said that if you asked a team of economists whether the price of potatoes today is efficient, the only way in which they could answer would be by a series of different questions. To answer the question, an economist would need to know a lot of things: the opportunity cost of land; transportation cost; how many potatoes get wasted along the way, and so on and so forth. Thus, even well-informed economists do not have enough information to know whether the price of potatoes today is efficient. Instead of asking for a catalog of information, a smart economist would investigate how the price came about. It can be inferred whether the price is efficient via a structural analysis of the market, and an analogous analysis can be performed with respect to 
the efficiency of law. Although in most situations there is not enough information available to tell whether a specific substantive law is efficient (there are too many side effects and pieces of information that escape our analysis), whether a law is efficient can be inferred by looking at how that law was generated and analyzing the lawmaking process that led to that law.

Over time, scholars of the Virginia School of Law and Economics (along with other scholars from other schools) came to identify themselves as "functionalist" as opposed to the "positivist" or "normativist". This functional approach gave a new generation of scholars an opportunity to revisit important questions concerning law and the institutional design of lawmaking.

\section{Tullock's Controversial Positions}

It became very clear during those dinner conversations that Tullock took very controversial positions that puzzled even scholars that were very close to him, including Charles Rowley, who edited many of Tullock's volumes. Rowley was British, and a true believer in the common law, and Tullock repeatedly criticized the common law from many directions. We will present some of his controversial positions on the evolution of common law using a litigation model.

When litigation is modeled as a rent-seeking game, the plaintiff and defendant select the optimal litigation effort to maximize their expected payoffs. Litigation outcome is, however, uncertain, and the plaintiff may prevail on the defendant, depending on a number of factors. According to Tullock's (1980a) rent-seeking framework, a party will be more likely to be successful in litigation, the more effort that party puts into evidence discovery and legal briefing compared to the opponent. Tullock (1980a) identified a so-called probability success function according to which the probability of winning the case for one party equals the 
ratio of the party's effort over the sum of total effort spent by both parties, i.e. the probability of party $i$ to prevail in court is $p_{i}=\frac{E_{i}}{E_{i}+E_{j}}$, where $E_{i}$ denotes party $i$ 's effort and $i=P, D$ identifies respectively the plaintiff and the defendant.

\subsection{Adversarial Versus Inquisitorial Legal System}

Tullock's critical approach to trials was most famously articulated in his book "Trials on Trial: The Pure Theory of Legal Procedure" (Tullock, 1980b). Trials can be easily seen through a rent-seeking lens. It became obvious to Tullock that the adversarial system of adjudication exacerbates rent-dissipation in litigation. Litigation can be analogized to a fixed-sum game. Because parties are fighting for a fixed sum, there is not much opportunity to gain from cooperation. One party's gain is the other party's loss, so litigation becomes a rent-seeking game. Parties compete for that fixed source by investing in litigation costs. In that respect, the inquisitorial system dilutes the incentives to invest in rent-seeking. In the inquisitorial system, there is a third party (the judge), which essentially adds an additional denominator in the rent-seeking function, which thus reduces the returns from litigation investments. The different litigation incentives created by an adversarial and inquisitorial system will be illustrated in the following, using the analytical framework proposed by Parisi (2002).

In the standard rent-seeking models, procedural aspects of legal systems are not taken into account. Adversarial and inquisitorial legal procedures differ as to the degree of control the judge has over the evidentiary process. In a typical adversarial proceeding, the judge plays no role in the evidentiary process and the result of the proceeding depends solely on the parties' litigation efforts. On the other side, in a typical inquisitorial proceeding, the judge determines the order of the evidence during the trial and evaluates the credibility and the relative strength 
of each piece of evidence discussed in court. Parisi (2002) captures Tullock's intuition and models the presence of inquisitorial elements of a proceeding in a rent-seeking framework, in order to study its effect on parties' litigation expenditures. Procedural rules rarely fit neatly in the adversarial or inquisitorial categories, often presenting elements of both. Hence, Parisi (2002) introduces an institutional variable, $w$, that measures the weight assigned to the inquisitorial element when a judge is an active player in the fact and legal truth-finding. This institutional variable allows one to measure the relative dominance of an inquisitorial procedure over the adversarial components.

Plaintiff and defendant invest in litigation effort, denoted respectively by $E_{P}$ and $E_{D}$. Each party's litigation cost is denoted as $c\left(E_{i}\right), i=P, D$. In the inquisitorial procedure, the judge invests effort $E_{J}$ in the evidence discovery. The total value of the case is denoted with $V$. In the presence of inquisitorial elements in the proceeding, the probability that each party will prevail in the proceeding depends not only on the plaintiff's and defendant's litigation efforts, but also on the judge's decisions. The expected litigation return of each party is a weighted average of the inquisitorial and adversarial components, where the weight is the institutional component $w \cdot{ }^{5}$

The plaintiff chooses his effort level $E_{P}$ in order to maximize the expected return from litigation:

$$
R_{P}^{e}=\left[w E_{J}+(1-w) \frac{E_{P}}{E_{P}+E_{D}}\right] V-c\left(E_{P}\right)
$$

\footnotetext{
${ }^{5}$ Following Parisi (2002), a change in the mix of adversarial and inquisitorial components $w$ should have no effect on the total return, but may change the plaintiff and defendant's returns from litigation.
} 
Similarly, the defendant chooses his effort level $E_{D}$ in order to minimize the expected costs from litigation:

$$
R_{D}^{e}=-\left[w E_{J}+(1-w) \frac{E_{P}}{E_{P}+E_{D}}\right] V-c\left(E_{D}\right)
$$

The Nash equilibrium expenditures are

$$
E_{P}^{*}=E_{D}^{*}=\frac{(1-w) V}{4 c}
$$

Analogously to a standard rent-seeking model, in a purely adversarial system, $(w=0)$, each party will invest one quarter of the full value of the case $V$. The total dissipation at equilibrium will be one half of the value of the case. When the proceeding presents an inquisitorial component $(w>0)$, each party will invest in litigation an effort which is always lower than the comparable effort in a purely adversarial system. ${ }^{6}$

From a normative perspective, this allows us to identify the optimal institutional choice of the legal procedure, summarized by the institutional variable $w$, that indicates the weight assigned to the proactive role of the court in truthfinding. As more weight is assigned to adversarially-produced evidence $w$, the litigation expenditures and total dissipation will increase. The adversarial procedure increases litigation expenditures and exacerbates total dissipation caused by rent-seeking. The presence of inquisitorial elements in the proceeding reduces total litigation expenditures the more weight is assigned to inquisitorially produced evidence, $w$. In other words, an increase in judicial scrutiny of the adversary

\footnotetext{
${ }^{6}$ Total dissipation increases monotonically in the number of participants $N$ in litigation, ranging from one half up to the full value of the case. See Dari-Mattiacci and Parisi (2005) on the mixed-strategy solution to Tullock's paradox. See also Higgins, Shugart and Tollison (1985) for rent-seeking contests with endogenously determined numbers of litigants.
} 
discovery decreases litigation expenditures. ${ }^{7}$ An analysis of comparative statics illustrates how the optimal weights placed on the adversarial and inquisitorial elements of the legal proceedings depend upon several factors, among which are the social relevance of the case under scrutiny, the degree of judicial inspection of the parties' evidence, the litigation investments, and the number of litigants involved in the litigation. In the case of multiple litigants, a higher level of $w$ may reduce the level of dissipation created by litigation, since each party faces reduced private incentives to invest in litigation in light of the higher weight assigned to inquisitorially-produced evidence. The same holds true in the face of an increase in the private cost of discovery for the parties.

In real life, legal systems exhibit a mix of inquisitorial and adversarial elements in the proceedings. A rationale can be found in the comparative advantage of courts in truth-finding compared to litigants. In a purely adversarial proceeding, the parties' private incentive to produce evidence may be misaligned with the socially optimal incentives. In other words, as pointed out by Posner (1999), the adversarial system may end up producing too much or too little evidence from an efficiency point of view. In an inquisitorial proceeding, instead, a (benevolent) judge is incentivized to seek truth until the social marginal benefit of producing additional evidence equals the social marginal cost of producing it. Yet, parties may have a comparative advantage (and a greater interest) in accessing and producing information. Hence, a mix of inquisitorial and adversarial elements may be socially optimal and superior to a purely adversarial or purely inquisitorial legal system.

\footnotetext{
${ }^{7}$ Not surprisingly, total discovery and litigation costs increase with the value of the case, $m_{\mathrm{A}}$, assessed on the basis of adversarially-produced evidence.
} 
The flip side of this analysis is that the higher litigation costs of the adversarial system make litigation less appealing. Litigation costs are like a tax. Considering the participation constraint, when parties invest more in equilibrium, they will also enter litigation less frequently. The analysis of the parties' incentives to engage in litigation can be carried out by extending Tullock's rent-seeking model to characterize the participation constraint of litigants. A prospective plaintiff will rationally file suit and initiate litigation if the expected return from litigation is non-negative, i.e. $\mathrm{R}_{\mathrm{P}}^{\mathrm{e}} \geq 0$. Similarly, a prospective defendant will choose to enter litigation when the expected return from defending in court is higher than satisfying the plaintiff's claim, i.e. $\mathrm{R}_{\mathrm{D}}^{\mathrm{e}} \leq-\mathrm{V}$.

Within the analytical framework proposed above, the plaintiff enters litigation at equilibrium when:

$$
\mathrm{R}_{\mathrm{P}}^{\mathrm{e}}=\left[w E_{J}+(1-w) \frac{E_{P}}{E_{P}+E_{D}}\right] V-c\left(E_{P}\right)>0
$$

Similarly, the defendant chooses to go to court at equilibrium only when the expected cost from litigation are lower than the payment $V$ demanded by the plaintiff:

$$
\mathrm{R}_{\mathrm{D}}^{\mathrm{e}}=-\left[w E_{J}+(1-w) \frac{E_{P}}{E_{P}+E_{D}}\right] V-c\left(E_{D}\right) \leq-V
$$

Interestingly, not all cases will drop out uniformly when litigation costs rise. The recent litigation literature has been exploring this question: what types of cases will be brought to litigation and actually litigated in one system versus the other?

\subsection{American Versus English Rule and the Efficient Selection of Cases}


An important factor that drives case selection is the application of the "English Rule" versus the "American Rule" with respect to legal fees. Under the "English Rule," the losing party pays not only his or her own expenses, but also the legal fees to the winning counter-part. Under the American Rule, each party instead pays for his or her own expenses regardless of who prevails in the suit.

Luppi and Parisi (2012) focus on the impact of alternative fee-shifting rules on the parties' litigation strategies and expenditures. Following Luppi and Parisi (2012), let us consider the following litigation context. A plaintiff suffers a loss $V>0$ caused by defendant. The plaintiff sues the defendant, who can raise a possible counterclaim at the trial, equal to $L \geq 0$. In the presence of asymmetric stakes, the plaintiff is awarded $V$ by the defendant, when there is a decision in favor of the plaintiff and the defendant is awarded $L$ by the plaintiff when there is a decision in favor of the defendant. The litigants face a dispute where $p$ denotes the winning probability for the plaintiff and forms a rational expectation of the probability of success in litigation. The plaintiff and defendant invest in litigation effort levels $E_{P}$ and $E_{D}$, respectively. The greater the litigation investment of each party compared to the other, the more likely that party will prevail in litigation. The probability the plaintiff wins the case is equal to $p\left(E_{P}, E_{D}\right)$ and is modeled according to Tullock's contest-success function $p\left(E_{P}, E_{D}\right)=\frac{E_{P}}{E_{P}+E_{D}}$.

Under the American rule, each party is responsible for their own litigation costs, regardless of who prevails at trial. Analytically, plaintiff and defendant invest in litigation efforts in order to maximize their expected return from litigation:

$$
R_{P}^{e}=p\left(E_{P}, E_{D}\right) V-\left(1-p\left(E_{P}, E_{D}\right)\right) L-E_{P}
$$




$$
R_{D}^{e}=\left(1-p\left(E_{P}, E_{D}\right)\right) V-p\left(E_{P}, E_{D}\right) L-E_{D}
$$

subject to the participation constraints that expected litigation returns are nonnegative, i.e. $R_{P}^{e} \geq 0$ and $R_{D}^{e} \geq 0$.

Under the English rule, the prevailing party receives compensation from the losing party for at least a fraction of the litigation costs incurred. Analytically, the winning party receives a fraction, denoted by $a$, of the litigation costs incurred and a fraction, denoted with $b$, of the total value of the case, equal to $V+L{ }^{8}$ Under the English rule, parties invest in litigation efforts in order to maximize their expected returns from litigation: ${ }^{9}$

$$
\begin{aligned}
& R_{P}^{e}=p\left(V+b(V+L)+a E_{P}\right)-(1-p)\left(L+b(V+L)+a E_{D}\right)-E_{P} \\
& R_{D}^{e}=(1-p)\left(V+b(V+L)+a E_{P}\right)-p\left(L+b(V+L)+a E_{D}\right)-E_{D}
\end{aligned}
$$

subject to the participation constraints that expected litigation returns are nonnegative, i.e. $R_{P}^{e} \geq 0$ and $R_{D}^{e} \geq 0$.

Unsurprisingly, under this set-up, equilibrium litigation efforts are higher under the English rule than under the American rule. However, higher litigation efforts cause a reduction of litigation rates for the same type of cases. While cases characterized by ratio $V / L$ equal to 3 can lead to litigation under the American rule, the ratio $V / L$ required to generate litigation under the English rule has a value of $k>3$. This implies that at equilibrium, litigation rates and total expected litigation costs decrease in the range $3 \leq V / L<k$ under an English rule.

\footnotetext{
${ }^{8}$ This explicit formulation is motivated, because in jurisdictions adopting the English rule, courts liquidate litigation costs on the basis of the fees established by the professional bar associations, computed according to the value of the case and the actual litigation costs (reflected by the number of hearings and motions filed, etc.).

${ }^{9}$ For clarity, the dependence of the probability function $p$ on $E_{P}$ and $E_{D}$ is omitted throughout the text.
} 
Fee-shifting rules affect case selection beyond the differences in litigation rates. ${ }^{10}$ Luppi and Parisi (2012) show that under the American rule parties litigate only cases with a very low probability of success and high stakes, whereas the opposite occurs under the English rule, where parties litigate only cases with a high probability of success and low stakes. Luppi and Parisi (2012) show that different procedural rules, such as fee-shifting rules, produce different case selection. In turn, different fee-shifting rules may cause different paths of evolution of judgemade law in common law systems.

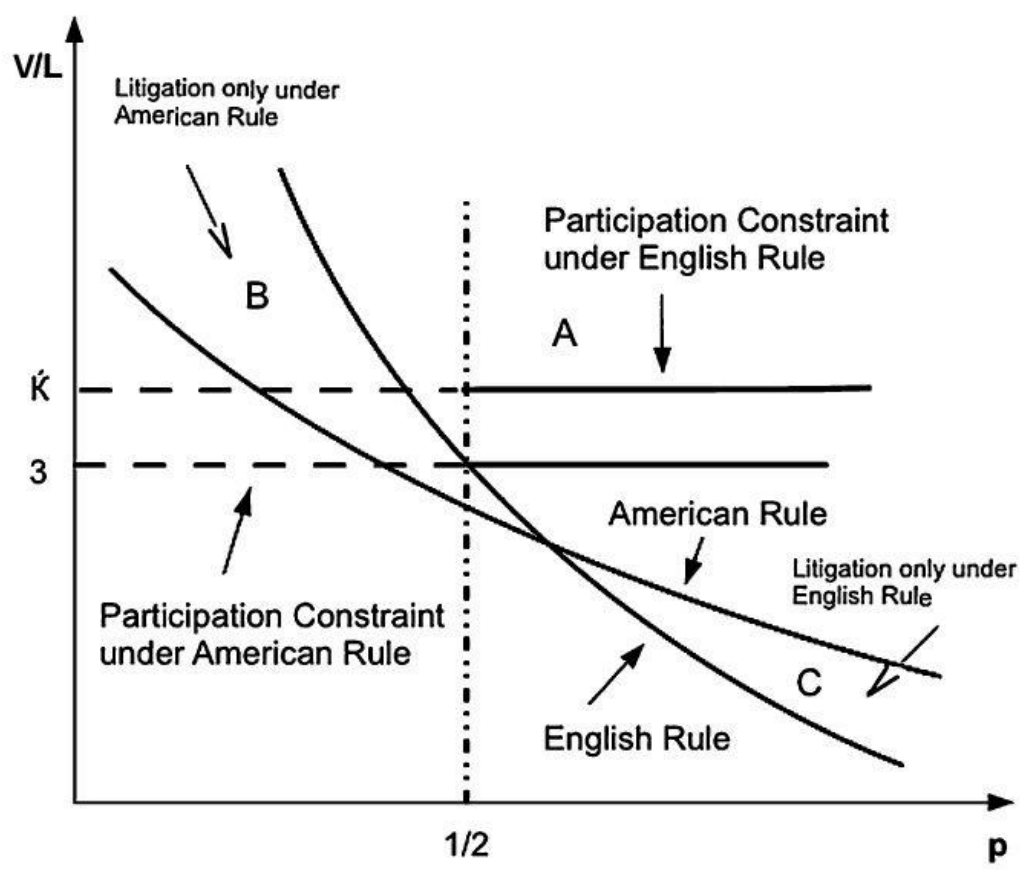

Figure 1 - Case selection: American vs. English rule (Luppi and Parisi, 2012)

To better appreciate this result, Figure 1 (Luppi and Parisi, 2012) plots the

\footnotetext{
${ }^{10}$ See also Priest (1977), Priest and Klein (1984), Fon and Parisi (2003), Fon, Parisi and Depoorter (2005) for early work on case selection in common law.
} 
break-even litigation hyperbolas, identifying the pair $\left(\frac{V}{L}, p\right)$ along which parties have a zero return from litigation, and participation constraints under the American rule and the English rule. The break-even litigation hyperbola have different curvatures and slopes under the English and American rules, due to the difference in litigation costs caused by the two fee-shifting rules. Break-even litigation hyperbolas are flatter under the American rule than under the English one.

Not surprisingly, cases characterized by higher probability of success are more likely to be filed under both fee-shifting rules, compared to cases with a lower probability of success. These cases are identified by region $A$ in Figure 1 and will be filed under both the American and English rules. The selection of cases in regions $B$ and $C$ is affected by the fee-shifting rule. Cases in region $B$, located in the north-west quadrant of Figure 1, will be filed only under the American rule. Cases in region B present a low probability of success, but high stakes. By contrast, cases in region $C$, located in the south-east quadrant of Figure 1, are characterized by a high probability of success, but low stakes. Those cases will only be filed under the English rule.

Dissipation of resources caused by litigation is higher under an American rule, consistently with Tullock's predictions. This can be intuitively explained by looking at the selection of cases under the two fee-shifting rules. While cases with high merits located in region $C$ are not filed because of the incidence of nonrecoverable litigation costs under the English rule, cases with low merit located in region $B$ are filed under the American rule. Intuitively, cases in Region $B$ are 
brought to court, despite the low probability of success, because the plaintiff will not compensate the defendant for litigation costs if he loses the case. ${ }^{11}$

For litigation to occur, defendant's participation constraint should also be satisfied. Defendant should prefer to litigate rather than paying the requested settlement amount. Carbonara, Parisi and Von Wangenheim (2015) have recently contributed to this trend of the literature to show how the merit of the case, the effectiveness of legal expenditures, and the amount of recoverable legal fees under the English rule, ${ }^{12}$ affect parties' litigation expenditures and their decisions to litigate. Contrary to the prevailing results, Carbonara, Parisi and Von Wangenheim (2015) identify a hidden virtue of the English rule over the American rule, showing that an increase in fee-shifting may reduce total litigation costs and lead to a desirable sorting of socially valuable litigation.

To illustrate the results put forth by Carbonara, Parisi and Von Wangenheim (2015), let us consider a sequential game in which the plaintiff decides whether to file the case, after which the defendant chooses whether to enter litigation or to pay the award $V$ to the defendant. If both parties enter litigation ("litigation stage"), they decide their effort levels in a simultaneous Tullock-Katz game. The probability that the plaintiff wins the case is modeled following Farmer and Pecorino (1999), and is given by $\left(E_{P}, E_{D}\right)=\frac{m E_{P}^{r}}{E_{D}^{r}+m E_{P}^{r}}$, where $m$ is the merit of the

\footnotetext{
${ }^{11}$ See Tullock (1997, 2004, 2005, p. 441, for the plaintiff's externality under the American rule. According to Fon and Parisi (2009) and Luppi and Parisi (2012, 2015), the selection of different cases under different fee-shifting rules leads to different paths of evolution of judge-made law. Once adjudicated, these cases will generate a negative flow of precedents, leading to a reduced likelihood of success of similar cases in the future. Region B may lead to bubbles of litigation, generating contractionary trends under the American rule, not otherwise observed under the English rule. On the contrary, cases in region $C$ will more likely generate a flow of positive precedents and adjudication of these cases will lead to the consolidation of judge-made rules. Region $\mathrm{C}$ will more likely foster consolidation of remedies and a greater stability of legal protection under the English rule.

${ }^{12}$ Any legal system using the English rule sets limitations on the amount of recoverable legal fees on the basis of the reasonableness and proportionality of the expenditures for the assertion and defense of the legal rights in question. See also Bungard (2006).
} 
case, and $r$ represents the effectiveness of legal expenditures. The analysis proceeds backward starting from the "litigation stage".

Analytically, under the American Rule, the plaintiff and the defendant invest in litigation efforts to maximize their expected returns from litigation:

$$
\begin{aligned}
& R_{P}^{e}=\pi V-E_{P} \\
& R_{D}^{e}=-\pi V-E_{D}
\end{aligned}
$$

By considering limited fee-shifting, under the English Rule, the losing party has to cover the winning party's expenditures up to a given threshold, the feeshifting limit, denoted by $d$. Parties invest in litigation efforts to maximize their returns from litigation:

$$
\begin{aligned}
& R_{P}^{e}=\pi\left(V-\max \left\{0, E_{P}-d\right\}\right)-(1-\pi)\left(E_{P}+\min \left\{E_{D}, d\right\}\right) \\
& R_{D}^{e}=\pi\left(-V-E_{D}-\min \left\{E_{P}, d\right\}\right)-(1-\pi) \max \left\{0, E_{D}-d\right\}
\end{aligned}
$$

The results from the equilibrium expenditures show that an increase in the fee-shifting limit, $d$, leads to a continuous shift from the American Rule $(d=0)$-under which both parties choose equilibrium investment-levels above the upper limit (i.e., $E_{P}, E_{D}>d$ ) -- to the English Rule ( $d$ unlimited) -- under which both parties choose equilibrium investment-levels below the upper limit (i.e., $0<$ $E P, E D<d)$.

Besides reducing overall litigation costs, the English Rule has another effect, that of optimally sorting the cases brought to courts. By analyzing the earlier stage of the game where parties choose whether to enter litigation, the results show that 
under the English Rule, an increase in the amount of recoverable legal fees generates a crowding-out effect of two less desirable categories of cases: frivolous cases characterized by very low merits, and strong cases with very high merit. For the first group of cases, plaintiff's participation constraint is violated and cases are not filed. For the second group of cases, defendant's participation constraint is violated and cases are settled. Litigation persists in the medium range, where parties' claims have comparable merits and where adjudication and legal precedents have the additional social benefit of reducing legal uncertainty. The adoption of the loser-pays principle hence reduces the wedge between the private and social incentives to litigate, promoting the adjudication of meritorious claims and counter-claims cases, where the existing law is either unsettled or ambiguous.

Additionally, increasing the cap on recoverable legal fees decreases the defendant's incentives to litigate more than it does the plaintiff's. Hence, this decreases the total number of cases contested, but increases average expenditures in those cases that do end up being litigated. From a rent-seeking point of view, the English rule can be seen as a contest where the winner receives compensation also for his own rent-seeking expenditures. Left alone, this would of course generate infinite expenditures. If by winning the rent-seeking contest, you were also reimbursed for your rent-seeking expenditures, you would see an escalation of effort toward infinity with a resulting Tullock paradox. This explains why legal systems that use the English Rule put a cap on recovery of expenses.

But most interesting is that under the English Rule, cases drop out at the two extremes: frivolous cases and strongly meritorious cases. The cases that remain in litigation are those that have balanced merits, and those are the cases that, from a social point of view, the society wants to see litigated, in order to promote clarity and certainty in the law. Frivolous cases should not be filed, and strong cases 
should be settled without litigation The English Rule creates this desirable selection effect.

\subsection{Napoleon Was Right: A Case For The Civil Code}

Equally controversial was Tullock's (1988) booklet entitled "Defending the Napoleonic Code over the Common Law" and "Why I Prefer Napoléon" (in "The Case Against the Common Law", published by the Locke Institute in 1997). There, Tullock suggested that, because of the nature of the common law, and its distinction between narrow holdings and dicta, the common law can only develop very tight, narrow rules. Likewise, the regulations that complement the common law tend to be very specific and narrow, tailoring to special interest groups. Narrow rules, then, are like small boats in the ocean.

The rules that are produced for civil codes, conversely, are broad and general in application. They are like large ships. In this metaphor, special-interest pressures on law function as waves. The small boat can be pushed around very easily by the waves, but the large ship remains more stable. It is much harder to manipulate lawmakers at the general level than it is to manipulate them at the narrow level through special interest pressures.

Accordingly, code provisions are very general, and thus can resist special interest pressures better than the narrow rules of the common law system. This stability of the civil code is supported by history: the 1804 Napoleonic Code is still in force in France, and the 1900 German Code is still in force in Germany. Conversely, special interest regulation changes quickly and abruptly. All it takes is a new special interest group with better power and a better ability to overcome collective action problems, and the special interest regulation is up for change. 


\section{Concluding Remarks}

It was not until the 21st Century that Gordon Tullock's approach to law and economics has been really understood. Although he began as an isolated voice in academia, Tullock's foundational work has given origin to a new methodological perspective in law and economics. There is still not much emphasis on Gordon Tullock's work in the standard law and economics scholarship, and this is probably because he proposed a methodological shift that was unfamiliar to neoclassical economics scholars. He was not attacking any of the results of the Chicago School or the Yale School. Instead, he was attacking their methodologies. Tullock thus laid the foundations for a completely different way of thinking about legal and institutional design: the "functional" approach, which now characterizes much of the new scholarship of the Virginia school of law and economics.

\section{References}

Bungard, B.C. (2006). Fee! Fie! Foe! Fum!: I Smell the Efficiency of the English Rule: Finding the Right Approach to Tort Reform. 31 Seton Hall Legislative Journal 1-64.

Calabresi, G. (1991). The Pointlessness of Pareto: Carrying Coase Further. 100 Yale Law Journal 1211-1237.

Carbonara, E., Parisi, F. \& Von Wangenheim, G. (2012). Rent-Seeking and Litigation: The Hidden Virtues of the Limited Fee Shifting. Review of Law and Economics 11.2 (2015): 113148.

Dari-Mattiacci, G., \& Parisi, F. (2005). Rents, dissipation, and lost treasures: Rethinking Tullock's paradox. Public Choice, 124, 411-422.

Farmer, A., \& Pecorino, P. (1999). Legal expenditure as a rent-seeking game. Public Choice, 100(3-4), 271-288. 
Fon, V., \& Parisi, F. (2003). Litigation and the evolution of legal remedies: A dynamic model. Public Choice, 116, 419-433.

Fon, V., \& Parisi, F. (2009). The Economics of Lawmaking. Oxford University Press.

Fon, V., Parisi, F., \& Depoorter, B. (2005) Litigation, judicial path-dependence, and legal change" 20 European Journal of Law and Economics 43-56.

Higgins, Richard S., William F. Shughart II, and Robert D. Tollison. Efficient rents, free entry and efficient rent seeking. Public Choice 46.3 (1985): 247-258.

Luppi, B. \& Parisi, F. (2012). Litigation and Legal Evolution: Does Procedure Matter?" Public Choice, 152, 181-201.

Luppi, B. \& Parisi, F. (2015). Rent-Seeking in the Law, pp. 293-307 in R. Congleton and A. Hillman (eds.), Companion to Rent-Seeking, Springer.

Posner, R. A. (1999). An economic approach to the law of evidence. Chicago Working Papers in Law \& Economics No. 66 (2nd Series).

Posner, R. A. \& Parisi, F. (1999). Analisi Economica del Diritto Privato e Commerciale: Una Rassegna, 34 Biblioteca delle Libertà 3-32.

Priest, G. L. (1977). The Common law process and the selection of efficient rules. Journal of Legal Studies, 6, 65-82.

Priest, G. L., \& Klein, B. (1984). The selection of disputes for litigation. Journal of Legal Studies, 13, 1-55.

Parisi, F. (2002). Rent-seeking through litigation: Adversarial and inquisitorial systems compared. International Review of Law and Economics, 22,193-216. 46

Rowley. C. (2012). The intellectual legacy of Gordon Tullock. Public Choice, 152(1), 29-

Tullock, G. (1980a). Efficient Rent-Seeking. In J.M. Buchanan, G. Tollison \& G. Tullock, Toward a Theory of the Rent-Seeking Society, 97-112. College Station: Texas A\&M University Press.

Tullock, G. (1980b). Trials on Trial: The Pure Theory of Legal Procedure, New York: Columbia University Press.

Tullock, G. (1988). Defending the Napoleonic Code over the Common Law, in Stuart S. Nagel (ed.), Research in Law and Policy Studies, 2, 2-27.

Tullock, G. (1997). The Case Against the Common law. The Blackstone Commentaries, Fairfax: Locke Institute. 
Tullock, G. (2004). On the efficient organization of trials. In C.K. Rowley (Ed.) The Selected Works of Gordon Tullock (Volume 1). Indianapolis: Liberty Funds.

Tullock, G. (2005). Rent seeking and the law. In C.K. Rowley (Ed.) The Selected Works of Gordon Tullock (Volume 5). Indianapolis: Liberty Funds. 